\begin{tabular}{l|l|l} 
Jurnal Eksplorasi Akuntansi (JEA) & $\begin{array}{l}\text { e-ISSN : 2656-3649 (Online) } \\
\text { hol. 3, No 3, Agustus 2021, Hal 705-719 }\end{array}$
\end{tabular}

\title{
Pengaruh Ukuran Pemerintah Daerah, Umur Pemerintah Daerah, Status Pemerintah Daerah, Jumlah Penduduk, Jumlah SKPD, Belanja Pegawai dan Leverage Terhadap Kemandirian Keuangan Daerah
}

\author{
Inul Rofiq ${ }^{*}$, Fefri Indra Arza ${ }^{2}$ \\ ${ }^{1,2}$ Fakultas Ekonomi, Universitas Negeri Padang \\ *Korespondensi: inulrofiq64@gmail.com
}

\begin{abstract}
This study aims to determine the effect of the size of the local government, the age of the local government, the status of the local government, the total population, the total of SKPD, employee expenditure and leverage on regional financial independence. The population in this study is Regency/City in West Sumatra Province in 2015-2019. This study uses secondary data. The sampling technique used the Total Sampling method with a sample of 19 districts/cities with a period of 5 years. Data analysis used multiple linear regression analysis. The results of the study indicate that the status of local government, population and leverage affect regional financial independence. Meanwhile, the size of the local government, the age of the local government, the number of SKPD and employee expenditures have no effect on regional financial independence.
\end{abstract}

Keywords: Employee expenditure; Leverage; Regional financial independence; The age of the local government; The status of the local government.

How to cite (APA $6^{\text {th }}$ style)

Rofiq. I \& Arza, F.I. (2021). Pengaruh Ukuran Pemerintah Daerah, Umur Pemerintah Daerah, Status Pemerintah Daerah, Jumlah Penduduk, Jumlah SKPD, Belanja Pegawai dan Leverage Terhadap Kemandirian Keuangan Daerah. Jurnal Eksplorasi Akuntansi. 3(3). 705-719.

\section{PENDAHULUAN}

Menurut Utami, B. (2018) tujuan otonomi daerah adalah untuk mewujudkan kemandirian daerah dalam peningkatan pelayanan dan pemberdayaan masyarakat sehingga meningkatkan kesejahteraan masyarakat. Tujuan dari otonomi daerah yaitu untuk meningkatkan pelayanan umum, meningkatkan kesejahteraan masyarakat dan meningkatkan daya saing pemerintah daerah guna tercapainya kesejahteraan dan kemandirian pada pemerintah daerah.

Implikasi dari pemberian kewenangan otonomi daerah adalah guna menuntut pelaksanaan pembangunan infrastruktur daerah, terutama pembangunan sarana dan prasarana umum. Pembangunan tersebut dapat dilaksanakan secara mandiri oleh daerah baik dari sisi perencanaan, pembangunan, serta pembiayaannya. Pembangunan ini diharapkan memberikan manfaat bagi daerah diantaranya meningkatkan kualitas pelayanan masyarakat, mendorong perkembangan perekonomian daerah, mendorong peningkatan pembangunan daerah disegala 
bidang, meningkatkan pendapatan asli daerah, dan mendorong kegiatan investasi Mukarramah, H. (2017).

Menurut Halim, A. (2007) ciri utama suatu daerah yang dapat melaksanakan otonomi yaitu kemampuan keuangan daerah. Daerah otonom memiliki kewenangan untuk dapat menggali sumber keuangan yang ada pada daerahnya, mengelola dengan menggunakan keuangannya sendiri dalam membiayai kegiatan pemerintahan. Pendapat asli daerah harus menjadi sumber utama dalam pembiayaan pelaksanaan pemerintah daerah sehingga dapat mengurangi ketergantungan akan bantuan dari pemerintah pusat. Sistem otonomi daerah pemerintah daerah mempunyai keleluasaan pengambilan keputusan dalam upaya pembangunan dan mengembangkan seluruh potensi yang ada untuk kesejahteraan masyarakat.

Namun, realita menunjukan bahwa belum keseluruhan pemerintahan daerah di Indonesia berhasil mencapai tingkat kemandirian yang diharapkan. Masih banyak pemerintah kabupaten/kota di daerah yang sangat bergantung pada dana perimbangan dari pemerintah pusat. Salah satu pemerintah daerah yang masih menerima dana perimbangan dari pemerintah pusat dalam porsi yang jauh lebih tinggi dibandingkan dengan pendapatan asli daerahnya adalah pemerintah kabupaten/kota di wilayah provinsi Sumatera Barat. Dalam rincian penerimaan dana perimbangan Provinsi di Indonesia dalam Anggaran Pendapatan Belanja Negara (APBN) tahun 2019, provinsi Sumatera Barat masuk dalam daerah 10 besar penerima dana perimbangan terbesar pada tahun 2019 yakni berupa Dana Alokasi Umum (DAU) (www.djpk.kemenkeu.go.id).

Dana Alokasi Umum (DAU) merupakan salah satu transfer dana pemerintah pusat ke pemerintah daerah yang bersumber dari pendapatan Anggaran Pendapatan Belanja Negara (APBN) yang dialokasikan dengan tujuan untuk pemerataan kemampuan keuangan antar daerah guna mendanai kebutuhan daerah dalam rangka pelaksanaan desentralisasi. Dikutip dari www.djpk.kemenkeu.go.id pada tahun 2019 bahwa Sumatera Barat masuk dalam 10 provinsi dengan penerimaan Dana Alokasi Umum (DAU) terbesar dengan nilai sebesar Rp 13,9 triliun. Hal ini mencerminkan masih besarnya ketergantungan pemerintah kabupaten/ kota di wilayah provinsi Sumatera Barat terhadap anggaran dana perimbangan dari pusat.

Halim (2013) menyatakan bahwa salah satu instrument untuk mengukur kinerja pemerintah daerah dalam mengelola keuangan daerah adalah dengan melakukan analisa rasio keuangan terhadap APBD yang telah ditetapkan dan disahkan. Penggunaan analisis rasio sebagai alat analisis keuangan secara luas sudah diterapkan pada lembaga perusahaan yang bersifat komersial, sedangkan pada lembaga publik khsusnya pemerintah daerah masih sangat terbatas. Kemandirian keuangan daerah dapat dilihat dengan cara membandingkan Pendapatan Asli Daerah dengan pendapatan daerah yang berasal dari transfer pemerintah pusat atau dari pinjaman Halim (2007).

Kemandirian keuangan pemerintah daerah tentunya dipengaruhi oleh banyak faktor, menurut Groves, S. M., W.M. Godsey, dan M.A. Shulman. (2001) faktor yang mempengaruhi kemandirian keuangan terdiri dari tiga kategori yaitu faktor lingkungan, faktor kesejahteraan, dan faktor finansial. Beberapa penelitian yang meneliti tentang hubungan faktor-faktor yang berpengaruh terhadap kemandirian keuangan pemerintah daerah menunjukan bahwa terdapat beberapa faktor yang berpengaruh terhadap kinerja keuangan pemerintah daerah di dalam dan luar negeri. Ukuran, umur, status, jumlah penduduk, jumlah Satuan Kerja Perangkat Daerah (SKPD), belanja pegawai dan leverage merupakan bagian dari faktor-faktor yang mempengaruhi keuangan.

Firmansyah, I. (2017) menyebutkan bahwa ukuran pemerintah daerah berpengaruh positif terhadap kemandirian keuangan pada daerah provinsi Lampung. Pemerintah daerah dengan total aset yang besar akan mampu menjalankan pemerintahan daerahnya dengan baik dan dengan leluasa memanfaatkan nilai aset yang besar untuk meningkatkan potensi pendapatan daerah. Pratiwi, N. (2016) melakukan penelitian pada kabupaten/kota di Indonesia 
mengenai Pengaruh karakteristik pemerintah daerah terhadap kemandirian finansial dan pengaruhnya pada pertumbuhan ekonomi dan indeks pembangunan manusia. Dari hasil penelitian ini, dapat diketahui bahwa umur pemerintah daerah berpengaruh positif terhadap kemandirian keuangan daerah kabupaten/kota di Indonesia.

Kuncahyono, H. (2015) melakukan penelitian di daerah Jawa Timur mengenai pengaruh karakteristik pemerintah daerah terhadap kemandirian keuangan pada pemerintah daerah. Dari hasil penelitian ini, diketahui bahwa status pemerintah daerah berpengaruh positif terhadap kemandirian keuangan pemerintah daerah. Anwar, D. K. (2019) melakukan studi tentang determinan kemandirian keuangan daerah yang dilakukan pada provinsi Jawa Timur. Dari hasil penelitian dapat diketahui bahwa populasi berpengaruh positif dan signifikan terhadap derajat kemandirian keuangan daerah.

Berdasarkan hasil penelitian Pratiwi, N. (2016) mengenai pengaruh karakteristik pemerintah daerah terhadap kemandirian keuangan serta dampaknya terhadap pertumbuhan ekonomi dan indeks pembangunan manusia. Diperoleh hasil penelitian bahwa jumlah SKPD berpengaruh positif yang signifikan terhadap kemandirian keuagam daerah kabupaten/kota di Indonesia. Firmansyah, I. (2017) melakukan penelitian di provinsi Lampung mengenai faktorfaktor yang mempengaruhi keuangan daerah di provinsi Lampung. Hasil dari penelitian ini menyebutkan bahwa variabel leverage berpengaruh positif dan signifikan terhadap kemandirian keuangan daerah.

Penelitian ini memiliki objek yang mencakup kabupaten/kota di Sumatera Barat dengan menggunakan analisis data panel dalam periode lima tahun, yakni tahun 2015-2019. Penelitian ini berbeda dengan penelitian sebelumnya. Pada penelitian ini peneliti menggunakan pengukuran terbaru dan mengganti objek dengan kabupaten/kota di Sumatera Barat, pembaharuan tahun pada penelitian dan peneliti juga menambahkan dua variabel independent yaitu Jumlah Penduduk dan Leverage. Berdasarkan uraian latar belakang permasalahan kemandirian keuangan daerah diatas, maka peneliti tertarik untuk meneliti kembali pengaruh ukuran pemerintah daerah, umur pemerintah daerah, status pemerintah daerah, jumlah penduduk, jumlah skpd, belanja pegawai dan leverage terhadap kemandirian keuangan daerah.

\section{REVIU LITERATUR DAN HIPOTESIS}

\section{Teori Keagenan (Agency Teory).}

Menurut teori keagenan, peran pemerintah pusat bertindak sebagai prinsipal yang memberikan wewenang kepada pemerintah daerah bertindak sebagai agen untuk mengelola pemerintahannya secara mandiri tanpa campur tangan dari pemerintah pusat. Pemerintah daerah sebagai agen dituntut untuk mengelola keuangan daerahnya secara mandiri dengan menggali sumber-sumber pendapatan daerah yang berpotensial untuk meningkatkan pendapatan daerahnya. Sedangkan kenyataannya pemerintah daerah belum mampu menggali potensi sumber pendapatan daerah sehingga masih membutuhkan bantuan dari pemerintah pusat Pratiwi (2016).

Teory Keagenan merupakan salah satu teori yang digunakan dalam suatu penelitian, seperti ekonomika, akuntansi, pemasaran dan manajemen strategik. Dalam literatur akuntansi, teori ini menggambarkan suatu pola hubungan kontraktual antara prinsipal dan agen. Dimana prinsipal sebagai orang yang memberikan amanah dan agen yang bertugas menjalankan amanah tersebut. Menurut Jensen, Meckling, dan Eisenhardt dalam buku Nahartyo, E., \& Utami (2019) mengatakan bahwa hubungan keagenan adalah suatu bentuk kontrak yang terjadi antara satu orang atau lebih. Dimana prinsipal sebagai orang yang mengatur orang lain dan agen adalah orang yang melaksanakan perintah dari seorang prisipal.

jadi, kaitan penelitian ini dengan teori yang digunakan adalah seberapa besar kemampuan pemerintah daerah dalam mengelola pemerintahannya dengan memanfaatkan 
sumberdaya daerah yang berpotensial sebagai sumber pendapatan utama. Dengan adanya sumber pendapatan utama pemerintah daerah maka akan dapat meningkatkan segi finansial guna memaksimalkan infrastruktur dan pelayanan kepada masyarakat agar tercapainya kemandirian daerah.

\section{Kemandirian Keuangan Daerah}

Keuangan daerah merupakan segala hak dan kewajiban yang bisa dinilai dengan mata uang, demikian pula dengan segala sesuatu baik yang berupa uang atau barang yang dapat dijadikan kekayaan daerah (Halim, 2007). Berdasarkan Undang-Undang Nomor 32 Tahun 2004, kemandirian keuangan daerah diartikan bahwa pemerintah dapat mengembangkan sendiri pembiayaan dan pertanggungjawaban keuangannya dalam rangka prinsip desentralisasi, dan membangun pemerintahan daerah sendiri.

\section{Ukuran Pemerintah Daerah}

Ukuran pemerintah daerah menggambarkan seberapa besar daerah tersebut dengan melihat total aset yang dimiliki oleh suatu daerah (Pratiwi, 2016). Dalam pengukurannya ukuran pemerintah daerah diukur dengan melihat total aset dalam suatu periode tertentu. Gomes, R. C., Alfinito, S., \& Albuquerque, P. H. M. (2013) mengatakan bahwa kota besar berkemungkinan besar dapat mengelola pendapatan dan belanja secara baik jika dibandingkan dengan kota kecil.

\section{Umur Pemerintah Daerah}

Setyaningrum, D.,\& Syafitri, F. (2012) menyebutkan bahwa umur pemerintah daerah adalah tahun dibentuknya suatu pemerintah daerah berdasarkan undang-undang pembentukan daerah tersebut. Menurut undang-undang No.23 Tahun 2014 pasal 1 mengatakan bahwa pemerintah daerah adalah penyelenggaraan pemerintahan oleh pemerintah daerah dan DPRD menurut asas otonomi dan tugas pembantu dengan prinsip otonomi seluas-luasnya dalam prinsip Negara Kesatuan Republik Indonesia tahun 1945. Pemerintah daerah adalah kepala daerah sebagai unsur penyelenggara pemerintahan daerah yang memimpin pelaksanaan urusan pemerintahan yang menjadi kewenangan wilayah otonom.

\section{Status Pemerintah Daerah}

Status pemerintah daerah merupakan suatu pengakuan nasional sebuah daerah sebagai suatu kabupaten atau kota. Kabupaten atau kota adalah pembagian wilayah administratif di Indonesia setelah provinsi. Secara umum, baik kabupaten atau kota memiliki wewenang yang sama yaitu mengatur dan mengurus pemerintahannya sendiri.

\section{Jumlah Penduduk}

Jumlah penduduk adalah jumlah manusia yang bertempat tinggal/berdomisili pada suatu wilayah daerah dan memiliki mata pencaharian tetap di daerah itu serta tercatat secara sah berdasarkan peraturan yang berlaku di daerah tersebut. Pencatatan atau peng-kategorian seseorang sebagai penduduk biasanya berdasarkan usia yang telah ditetapkan. Semakin besar populasi penduduk berarti tingkat permintaan dan penawaran akan meningkat dan menguntungkan banyak pihak dengan kata lain semakin besar jumlah penduduk juga akan meningkatkan perekonomian suatu daerah.

\section{Jumlah SKPD}

Satuan Kerja Perangkat Daerah (SKPD) adalah perangkat daerah pada pemerintah daerah yang berfungsi sebagai pusat pertanggungjawaban pembangunan daerah dengan dipimpin oleh kepala satuan kerja selaku pengguna anggaran/pengguna barang. contohnya: SKPD dinas 
kesehatan, SKPD dinas pendidikan, SKPD dinas pemuda dan olahraga, dan lain sebagainya.SKPD adalah pelaksanaan fungsi eksekutif yang harus berkoordinasi agar penyelenggaraan pemerintahan berjalan dengan baik (Undang-undang No.32 pasal 120 Tahun 2004).

\section{Belanja Pegawai}

Berdasarkan Undang-Undang Nomor 45 Tahun 2007 tentang APBN, menjelaskan bahwa belanja pegawai adalah belanja pemerintah pusat dan digunakan untuk membayar pegawai pemerintah pusat, pensiunan, Tentara Nasional Indonesia/ Kepolisian negara dan pejabat negara, baik yang menjalankan tugas di dalam maupun di luar negeri, digunakan sebagai kompensasi atas pekerjaan yang telah selesai, kecuali untuk pekerjaan yang berkaitan dengan pembentukan modal.

\section{Leverage}

Rasio leverage adalah rasio total hutang dalam perusahaan terhadap rata-rata ekuitas. Leverage menggambarkan struktur modal suatu perusahaan, sehingga dapat dilihat seberapa besar kewajiban yang tidak bisa dibayarkan oleh perusahaan. Leverage adalah hasil penggunaan dana biaya tetap untuk meningkatkan keuntungan bagi pemegang saham Ridwan., \& B.(2005).

\section{Pengaruh Ukuran Pemerintah Daerah Terhadap Kemandirian Keuangan Daerah}

Ukuran daerah menggambarkan seberapa besar daerah tersebut dengan melihat total sumber daya ekonomi yang dimiliki daerah atau asetnya. Ukuran pemerintah daerah diukur dengan melihat total aset dalam satu periode tertentu. Gomes, R. C., Alfinito, S., \& Albuquerque, P. H. M. (2013) menjelaskan bahwa kota besar lebih mungkin untuk mengelola pendapatan dan belanja lebih baik daripada kota kecil. Menurut penelitian Kuncahyono, H. (2015) menunjukan bahwa ukuran pemerintah daerah berpengaruh signifikan terhadap kemandirian keuangan pemerintah daerah.

Kabupaten/ Kota dengan total aset yang lebih besar akan lebih kompleks dalam menjaga dan mengelola asetnya sehingga pemerintah daerah perlu mengungkapkan lebih lanjut tentang aset yang dimiliki pemeliharaan dan pengelolaannya dengan lebih baik. Pratiwi, N. (2016) juga melakukan penelitian mengenai ukuran pemerintah daerah terhadap kemandirian keuangan daerah, hasilnya menunjukan bahwa ukuran pemerintah daerah berpengaruh positif terhadap kemandirian keuangan daerah. Semakin besar ukuran pemerintah daerah diharapkan dapat meningkatkan pelayanan kepada masyarakat kedepannya melalui dukungan dari aset yang ada, sehingga kinerja pemerintah daerah juga akan meningkat dikarenakan sumber daya dan fasilitas yang dimiliki pemerintah memadai.

H1: Ukuran pemerintahan daerah berpengaruh positif terhadap kemandirian keuangan daerah

\section{Pengaruh Umur Pemerintah Daerah Terhadap Kemandirian Keuangan Daerah}

Umur pemerintahan daerah adalah tahun terbentuknya pemerintahan daerah sesuai dengan peraturan perundang-undangan yang ditetapkan oleh daerah yang bersangkutan. Umur pemerintahan daerah merupakan salah satu faktor yang mempengaruhi tingkat pengungkapan wajib pada Laporan Keuangan Pemerintahan Daerah (LKPD). Penelitian yang dilakukan oleh Pratiwi, N. (2016) menunjukan bahwa umur pemerintah daerah berpengaruh positif dan signifikan terhadap kemandirian keuangan daerah.

Semakin lama atau semakin tua suatu pemerintah daerah berarti pemerintahan daerah tersebut sudah memiliki banyak pengalaman dalam mengelola daerahnya. Pengalaman yang dimaksud adalah bagaimana pemerintah daerah menjalankan sistem administrasinya yang terdiri dari pencatatan dan pelaporan keuangan. Semakin berpengalaman suatu pemerintah 
daerah diharapkan proses administrasi tersebut bisa berjalan secara efektif dan efisien sehingga secara langsung akan berpengaruh pada peningkatan suatu daerah.

H2: Umur pemerintah daerah berpengaruh positif terhadap kemandirian keuangan daerah

\section{Pengaruh Status Pemerintah Daerah Terhadap Kemandirian Keuangan Daerah}

Status pemerintah daerah adalah wilayah yang diakui secara nasional sebagai kabupaten atau kota. Kabupaten atau kota adalah bagian administratif setelah provinsi Indonesia. Secara umum, daerah dan kota memiliki kewenangan yang sama, yaitu mengatur dan menjalankan pemerintahannya sendiri. Pada penelitian ini status daerah digunakan untuk membedakan antara Kota dan Kabupaten.

Penelitian Kuncahyono, H. (2015) Menunjukkan bahwa status pemerintah daerah berdampak positif terhadap kemandirian keuangan daerah, selanjutnya pada penelitian Pratiwi, N. (2016) juga menyatakan bahwa status pemerintah daerah berdampak positif terhadap kemandirian keuangan daerah. Pemerintah kota pada umumnya memiliki sumber daya ekonomi dan sumber daya manusia yang lebih baik dari pemerintah kabupaten, sedangkan daerah yang sudah lama berdiri akan lebih mandiri dalam hal ekonomi dibandingkan daerah yang baru pemekaran. Semakin memadai sumber daya yang ada maka meningkatkan kinerja pemerintah daerah menjadi lebih baik. Kinerja pemerintah yang memadai tentunya akan meningkatkan kesejahteraan pada masyarakat. Kinerja pemerintah yang memadai tentunya akan meningkatkan kesejahteraan pada masyarakat.

H3: Status pemerintah daerah berpengaruh positif terhadap kemandirian keuangan daerah

\section{Pengaruh Jumlah Penduduk Terhadap Kemandirian Keuangan Daerah}

Menurut Chairany, M. (2010) penduduk adalah semua orang yang berdomisili di wilayah geografis suatu negara selama enam bulan atau lebih dan atau mereka yang berdomisili kurang dari enam bulan tetapi bertujuan untuk menetap. Penduduk di suatu daerah tentunya memiliki peran yang berbeda-beda. Penduduk bisa menjadi konsumen dan produsen.

Semakin besar populasi penduduk akan meningkatkan permintaan dan penawaran sehingga menguntungkan banyak pihak, dengan demikian semakin besar jumlah penduduk akan berimplikasi pada peningkatan berbagai macam kegiatan ekonomi disuatu wilayah. Melalui kegiatan ekonomi tersebut maka akan meningkatkan pungutan yang akan masuk ke dalam kas daerah seperti pajak maupun retribusi daerah. Pajak dan retribusi daerah merupakan sumber pendapatan asli daerah yang mendukung terciptanya kemandirian keuangan daerah.

H4: Jumlah penduduk berpengaruh positif terhadap kemandirian keuangan daerah

\section{Pengaruh Jumlah SKPD Terhadap Kemandirian Keuangan Daerah}

Jumlah Satuan Kerja Perangkat Daerah (SKPD) mempresentasikan diferensiasi fungsional dipemerintah Indonesia. SKPD bertugas untuk menjalankan fungsi eksekutif dan berkoordinasi untuk memastikan tata kelola yang baik. SKPD merupakan instansi daerah yang ada di lingkungan pemerintah daerah dan mempunyai kewenangan untuk mengawasi keuangan daerah, khususnya kewenangan penggunaan anggaran / komoditas daerah.

Hasil penelitian Pratiwi, N. (2016) menyatakan bahwa jumlah SKPD berpengaruh positif terhadap kemandirian keuangam daerah. semakin banyak jumlah SKPD maka dapat diharapkan pelayanan yang lebih baik kepada masyarakat dan kinerja pemerintah daerah juga semakin baik. Sesuai dengan Permendagri Nomor 13 Tahun 2006 tugas SKPD yaitu penyusunan APBD, pelaksanaan dan penatausahaan belanja, pelaksanaan dan penataan pendapatan, akuntansi dan pelaporan sampai kepada perubahan APBD.

Penggunaan APBD / komoditas adalah untuk memberikan pelayanan kepada masyarakat terkait dengan tanggung jawab dan kewenangan SKPD, sehingga semakin banyak 
jumlah SKPD maka dapat diharapkan pelayanan yang lebih baik kepada masyarakat dan kinerja pemerintah daerah juga semakin baik.

H5: Jumlah SKPD berpengaruh positif terhadap kemandirian keuangan daerah

\section{Pengaruh Belanja Pegawai Terhadap Kemandirian Keuangan Daerah}

Belanja pegawai adalah pengeluaran kompensasi dalam bentuk uang dan barang yang ditetapkan sesuai dengan ketentuan peraturan perundang-undangan bagi pegawai pemerintah, pegawai negeri (PNS), dan pegawai yang bekerja yang belum menjabat sebagai pegawai negeri berupa kompensasi atas pekerjaan yang dilakukan, namun tidak berlaku pada pekerjaan yang berhubungan dengan pembentukan modal (Peraturan Pemerintah No. 21 Tahun 2004 tentang Penyusunan Rencana Kerja).

Belanja Pegawai termasuk dalam belanja operasi, pemeliharaan sarana dan prasarana publik yang merupakan semua pengeluaran Pemerintah Daerah yang berhubungan dengan aktivitas atau pelayanan publik. Semakin besar komposisi belanja pegawai semakin besar belanja operasi dan pemeliharaan sarana publik. Yang berarti kinerja Pemerintah Daerah akan semakin baik.semakin besar komposisi belanja pegawai semakin besar belanja operasi dan pemeliharaan sarana publik. Yang berarti kinerja Pemerintah Daerah akan semakin baik.

H6: Belanja pegawai berpengaruh positif terhadap kemandirian keuangan daerah

\section{Pengaruh Leverage Terhadap Kemandirian Keuangan Daerah}

Leverage menunjukan utang yang dimiliki oleh perusahaan. Bagi perusahaan komersial atau swasta, rasio leverage biasanya digunakan untuk mengukur rasio antara dana yang disediakan oleh pemilik dan dana yang dipinjam perusahaan dari kreditor, Halim, A. (2007). Pada sektor publik, khususnya entitas pemerintah daerah, rasio leverage digunakan untuk mengukur rasio hutang terhadap ekuitas (aset bersih pemerintah daerah). Penelitian yang dilakukan oleh Firmansyah, I. (2017) menunjukan bahwa leverage berpengaruh positif terhadap kemandirian keuangan daerah. Dimana pemerintah Daerah mampu menggunakan sumber-sumber pinjaman dari luar untuk mengurus pemerintahaan daerahnya secara efektif, sehingga meningkatkan kemandirian keuangan daerah.

Dapat diasumsikan bahwa jika suatu daerah dapat meningkatkan leverage dengan menggunakan dana ekuitasnya untuk menutupi kewajiban, hal itu berarti kewajiban entitas dapat diminimalisir, sehingga dapat menaikan tingkat kemandirian daerah dengan tidak terbebaninya daerah oleh sumber pendapatan dana dari pihak eksternal berupa pinjaman atau utang.

H7: Leverage berpengaruh positif terhadap kemandirian keuangan daerah

\section{METODE PENELITIAN}

Populasi dalam penelitian ini adalah pemerintah daerah yaitu Laporan Keuangan Pemerintah Daerah Kabupaten/Kota di Sumatera Barat sejak tahun 2015 sampai 2019 yang telah di audit oleh Badan Pemeriksaan Keuangan (BPK). Pada penelitian ini populasi yang digunakan adalah kabupaten/kota di provinsi Sumatera Barat yang berjumlah 19 kabupaten/ kota, sedangkan jumlah penduduk diambil dari data statistik Badan Pusat Statistik (BPS) dan Satuan Kerja Perangkat Daerah (SKPD) di ambil dari data yang di publiskasikan oleh website Badan Kepegaiwaian dan Pengembangan Sumber Daya Manusia (BKPSDM). Dari populasi tersebut semuanya di jadikan sampel sehingga penelitian ini disebut juga penelitian sensus (populasi). Penelitian ini menggunakan teknik total sampling, Artinya pada penelitian ini seluruh populasi akan dijadikan sampel dalam penelitian. 


\section{Jenis dan Sumber Data}

Dalam penelitian ini data yang digunakan berupa data dokumentasi. Martono, N. (2015) mendefenisikan dokumentasi sebagai suatu metode mengumpulkan berbagai benda atau objek yang memiliki karakterisktik berupa teks tertulis yang berkaitan dengan penelitian. Pada penelitian ini data yang digunakan berupa yaitu data sekunder yang di ambil dari website Direktorat Jendral Perimbangan Keuangan www.djpk.kemenkeu.go.id, BPS dan jumlah SKPD kabupaten/Kota yang di publikasi.

\section{Variabel Dependen (Y)}

\section{Kemandirian Keuangan Daerah}

Variabel dependen dalam penelitian ini adalah indikator Kemandirian Keuangan Pemerintah Daerah yaitu Rasio Kemandirian. Rasio ini menggambarkan tingkat kemandirian daerah dalam menyediakan kebutuhan pendanaan pembangunan di daerah.

$$
\text { Rasio Kemandirian }=\frac{\text { Total } P A D}{\text { Bantuan Pemerintah Pusat } / \text { Provinsi }+ \text { Pinjaman }} \text { X100\% }
$$

\section{Variabel Independen $(\mathrm{X})$}

\section{Ukuran Pemerintah Daerah}

Ukuran pemerintah daerah pada penelitian ini menggunakan total aset yang dimiliki suatu pemerintah daerah. Patrick, P. A. (2007) menggunakan pendapatan untuk ukuran daerah. Penelitian menggunakan total aset (aktiva) untuk mengukur ukuran daerah dengan pertimbangan karena nilai aktiva lebih stabil daripada nilai penjualan bersih dan kapitalisasi pasar.

\section{Ukuran Daerah $=$ Log Total Aset}

\section{Umur Pemerintah Daerah}

Umur pemerintah daerah dalam penelitian ini mengacu pada usia sejak dibentuknya pemerintah daerah atau disahkan sebagai pemerintah kabupaten/kota yang dihitung dari tahun pengesahan hingga tahun pengamatan.

\section{Status Pemerintah Daerah}

Status daerah pada penelitian ini digunakan menggunakan variabel dami. Jika status daerah adalah Kabupaten maka akan diberi skor (0) dan jika status daerah adalah Kota maka akan diberi skor (1).

\section{Jumlah Penduduk}

Dalam penelitian ini jumlah penduduk diukur menggunakan proyeksi dengan dasar sensus penduduk tahun 2015-2019.

\section{Jumlah SKPD}

Jumlah SKPD diukur dengan menggunakan seluruh total SKPD yang terdapat dalam suatu daerah.

\section{Belanja Pegawai}

Belanja Pegawai dihitung dari persentase Belanja Pegawai dibagi Belanja Daerah.

$$
\text { Peroporsi BP }=\frac{\text { BelanjaPegawai }}{\text { BelanjaDaerah }} \times 100 \%
$$




\section{Leverage}

Leverage merupakan perbandingan antara utang dan ekuitas dana yang dimiliki oleh pemerintahan daerah Halim, A. (2007).

$$
\text { Leverage }=\frac{\text { TotalUtang }}{\text { TotalEkuitasDana }} \times 100 \%
$$

\section{HASIL DAN PEMBAHASAN}

Tabel 1

\section{Hasil Analisis Statistik Deskriptif}

\begin{tabular}{|c|c|c|c|c|c|}
\hline \multicolumn{6}{|c|}{ Descriptive Statistics } \\
\hline & $\mathrm{N}$ & Minimum & Maximum & Mean & $\begin{array}{c}\text { Std. } \\
\text { Deviation }\end{array}$ \\
\hline KKD & 74 & 4.1395267 & 18.73295 & 9.989596 & 3.904544 \\
\hline Ukuran Pemda & 74 & 11.914696 & 12.38971 & 12.18442 & 0.106365 \\
\hline Umur Pemerintah & 74 & & & & \\
\hline Daerah & 14 & 11 & 235 & 74.08 & 64.902 \\
\hline Status & 74 & 0 & 1 & 0.28 & 0.454 \\
\hline LAG_JP & 74 & 50883 & 491280 & 253918.8 & 139053.3 \\
\hline LAG_JS & 74 & 26 & 47 & 37.7 & 6.043 \\
\hline Belanja Pegawai & 74 & 29.261 & 65.45852 & 49.02203 & 8.379131 \\
\hline Leverage & 74 & 0.0181279 & 2.244142 & 0.693196 & 0.481881 \\
\hline Valid N (listwise) & 74 & & & & \\
\hline
\end{tabular}

Berdasarkan tabel 1 di atas, variabel ukuran pemerintah daerah memiliki rata-rata 12.18442 dengan nilai ukuran pemda tertinggi (maksimum) sebesar 12.38971 dan nilai ukuran pemda terendah (minimum) sebesar 11.914696. Standar deviasi atau simpangan baku adalah sebesar 0.106365. Variabel umur pemerintah daerah rata-rata 74.08 dengan nilai umur pemerintah daerah tertinggi (maksimum) sebesar 235 tahun dan nilai umur pemerintah daerah terendah (minimum) sebesar 11 tahun. Standar deviasi atau simpangan baku adalah sebesar 64.90. Variabel Status memiliki rata-rata 0.28 dengan nilai status tertinggi (maksimum) sebesar 1 dan nilai status terendah (minimum) sebesar 0. Standar deviasi atau simpangan baku adalah sebesar 0.45. Variabel LAG_JP memiliki rata-rata 253918.8 dengan nilai jumlah penduduk tertinggi (maksimum) sebesar 491280 (491.280 jiwa) dan nilai jumlah penduduk terendah (minimum) sebesar 50883 (50.883 jiwa). Standar deviasi atau simpangan baku adalah sebesar 139053.3. Variabel LAG_JS memiliki rata-rata 37.7 dengan nilai jumlah SKPD tertinggi (maksimum) sebesar 47 SKPD dan nilai jumlah SKPD terendah (minimum) sebesar 26 SKPD. Standar deviasi atau simpangan baku adalah sebesar 6.04. Variabel Belanja Pegawai memiliki rata-rata 49.02 dengan nilai jumlah belanja pegawai tertinggi (maksimum) sebesar 65.45 dan nilai belanja pegawai terendah (minimum) sebesar 29.26. Standar deviasi atau simpangan baku adalah sebesar 8.37. Variabel Leverage memiliki rata-rata 0.69 dengan nilai jumlah leverage tertinggi (maksimum) sebesar 2.24 dan nilai leverage terendah (minimum) sebesar 0.01. Standar deviasi atau simpangan baku adalah sebesar 0.48. 


\section{Uji Asumsi Klasik}

\section{Uji Normalitas}

Uji normalitas berfungsi untuk menguji apakah data yang digunakan dalam penelitian telah berdistribusi normal atau tidak. Uji normalitas yang digunakan dalam penelitian ini adalah uji statistik Kolmogorov-Smirnov Test dengan tingkat signifikansi 5\%. Data yang berdistribusi normal memiliki nilai signifikansi $>0,05$. Apabila nilai signifikansi data penelitian lebih kecil dari 0,05 maka data tersebut tidak berdistribusi normal. Hasil uji normalitas pada penelitian ini memiliki probabilitas tingkat signifikasi 0,200 di atas nilai signifikasi kepercayaan 0,05. Ini berarti data penelitian ini berdistribusi secara normal.

\section{Uji Multikoliniearitas}

Uji Multikolinearitas berfungsi untuk mengetahui apakah pada model regresi terdapat korelasi antar variabel independen. Untuk mendeteksi ada atau tidaknya multikolinieritas di dalam model regresi dapat dilihat dari besarnya nilai Tolerance dan VIF-nya (Variance Inflation Factor). Regresi bebas dari masalah Multikolinieritas jika nilai Tolerance lebih dari 10 persen $(0,10)$ dan nilai VIF kurang dari 10,00 Ghozali, I. (2011). Berdasarkan hasil uji multikolinieritas menunjukan bahwa nilai VIF masing-masing variabel terlihat memiliki nilai VIF $<10$ dan nilai tolerance $>0,10$ sehingga bisa dikatakan bahwa tidak terjadi gejala multikolinieritas.

\section{Uji Heterokedastisitas}

Uji heterokedastisitas berfungsi untuk menguji pada model regresi apakah terdapat ketidaksamaan varian antara satu residual pengamatan ke pengamatan yang lain. Berdasarkan menunjukan bahwa setiap variabel pada penelitian memiliki nilai signifikansi pada variabel independen $>0,05$. Sehingga dapat disimpulkan data penelitian tidak mengalami heterokedastisitas.

\section{UJi Autokorelasi}

Uji autokorelasi berfungsi untuk mengetahui pada model regresi apakah terjadi hubungan antara kesalahan pengganggu pada periode $t$ dengan kesalahan pengganggu pada periode $t-1$ (sebelumnya). Berdasarkan hasil pengujian autokorelasi menunjukan bahwa, dU $<\mathrm{dW}<4$-dU $(1.8343<2.130<2.1657)$ maka dapat disimpulkan bahwa tidak terjadi auto korelasi antar variabel independen pada penelitian ini, sehingga model regresi layak digunakan.

\section{PEMBAHASAN HASIL PENELITIAN}

\section{Pengaruh Ukuran Pemerintah Daerah Terhadap Kemandirian Daerah}

Hasil pengujian hipotesis pertama memiliki nilai t sebesar 1.507 dan nilai koefisien regresi sebesar 7.318 dengan nilai sig. 0.137. Hal ini berarti hipotesis petama tidak berpengaruh terhadap kemandirian keuangan daerah karena nilai sig. $>\alpha(0.05)$, yaitu $0.137>$ 0.05 . Artinya ukuran pemerintah daerah tidak berpengaruh terhadap kemandirian keuangan daerah. Hasil ini memiliki arti bahwa besarnya ukuran pemerintah daerah yang dilihat dari total aset daerah tidak menjamin daerah tersebut memiliki kemandirian keuangan daerah yang baik.

Dapat dilihat dari daerah dengan total aset yang besar yaitu kabupaten Dharmasraya dengan total aset Log 12.344 dalam skala 5 tahun memiliki tingkat kemandirian daerah sebesar rata-rata 8,9. Sedangkan pada kota Sawahlunto dengan total aset yang lebih kecil yakni sebesar Log 11.893 dalam skala 5 tahun memiliki tingkat kemandirian daerah sebesar rata-rata 28. Hal ini dapat menjelaskan bahwa daerah dengan jumlah aset yang besar tidak berpengaruh terhadap kemandirian keuangan daerah. 
Tidak berpengaruhnya ukuran pemerintah daerah yang dilihat dari total aset terhadap kemandirian keuangan daerah mengindikasikan bahwa peran total aset dalam meningkatkan kemandirian keuangan daerah belum berjalan sebagaimana mestinya. Ini bisa disebabkan oleh banyaknya aset yang kurang produktif Minarsih, R. A. (2015). Aset kurang produktif merupakan aset yang tidak menghasilkan pengembalian seperti melakukan investasi pada properti atau kendaraan yang tidak menghasilkan pendapatan dari waktu ke waktu.

\section{Pengaruh Umur Pemerintah Daerah Terhadap Kemandirian Keuangan Daerah}

Hasil pengujian hipotesis kedua memiliki nilai t sebesar 1.482 dan nilai koefisien regresi sebesar 0.013 dengan nilai sig. 0.143 . Hal ini berarti umur pemerintah daerah tidak berpengaruh terhadap realisasi pendapatan asli daerah karena nilai sig. $>\alpha(0.05)$, yaitu 0.143 $>0.05$ Berdasarkan hasil uji t dapat disimpulkan bahwa hipotesis kedua umur pemerintah daerah tidak berpengaruh signifikan terhadap kemandirian keuangan daerah.

Pada penelitian ini kota Bukittinggi dengan usia tertua yakni 235 tahun memiliki ratarata kemandirian keuangan daerah sebesar 15,72\% tahun 2015 hingga 2019. Sedangkan kota Payakumbuh yang memiliki usia 49 tahun memiliki rata-rata kemandirian keuangan daerah sebesar 16,12 tahun 2015 hingga tahun 2019\%. Dari data ini dapat disimpulkan bahwa umur pemerintah daerah tidak berpengaruh terhadap kemandirian keuangan daerah.

Pengaruh negatif umur pemerintahan daerah terhadap kemandirian keuangan daerah mengindikasikan bahwa apabila suatu daerah yang memiliki umur administrasi lebih lama atau lebih tua belum tentu daerah tersebut lebih berpengalaman dalam mengelola pemerintahan daerahnya jika dibandingkan dengan daerah yang memiliki usia yang lebih muda. Hal ini menunjukan bahwa semakin lama suatu pemerintah daerah berdiri tidak dapat menjamin bahwa pemerintah daerah bisa lebih baik dalam meningkatkan rasio kemandirian keuangan daerahnya.

\section{Pengaruh Status Pemerintah Daerah Terhadap Kemandirian Keuangan Daerah}

Hasil pengujian hipotesis ketiga memiliki nilai t sebesar 2.498 dan nilai koefisien regresi sebesar 4.119 dengan nilai sig. 0.015. Hal ini berarti status pemerintah daerah berpengaruh terhadap kemandirian keuangan daerah karena nilai sig. $<\alpha(0.05)$, yaitu 0.015 $<0.05$ Berdasarkan hasil uji $\mathrm{t}$ dapat disimpulkan bahwa status pemerintah daerah mempengaruh kemandirian keuangan daerah. Status pemerintah daerah mempunyai pengaruh terhadap kemandirian keuangan daerah, perbedaan kota dan kabupaten dapat dilihat dari dua sisi, antara lain pendidikan, insfrastruktur, dan kondisi sosial masyarakat kota yang lebih baik sehingga status pemerintah daerah dapat mempengaruhi kemandirian keuangan pemerintah daerah.

Secara umum, daerah dan kota memiliki kewenangan yang sama, yaitu mengatur dan menjalankan pemerintahannya sendiri. dimana pemerintah kota pada umumnya memiliki sumber daya ekonomi dan sumber daya manusia yang lebih baik dari pemerintah kabupaten. Secara umum, daerah dan kota memiliki kewenangan yang sama, yaitu mengatur dan menjalankan pemerintahannya sendiri. dimana pemerintah kota pada umumnya memiliki sumber daya ekonomi dan sumber daya manusia yang lebih baik dari pemerintah kabupaten. Semakin memadai sumber daya yang ada maka meningkatkan kinerja pemerintah daerah menjadi lebih baik.

\section{Pengaruh Jumlah Penduduk Terhadap Kemandirian Keuangan Daerah}

Hasil pengujian hipotesis keempat memiliki nilai t sebesar 2.171 dan nilai koefisien regresi sebesar 1.731E-5 dengan nilai sig. 0.034. Hal ini berarti jumlah penduduk berpengaruh terhadap kemandirian keuangan daerah karena nilai sig. $<\alpha(0.05)$, yaitu $0.034<0.05$ 
Berdasarkan hasil uji $\mathrm{t}$ dapat disimpulkan bahwa jumlah penduduk mempengaruhi kemandirian keuangan daerah.

Peningkatan Jumlah Penduduk akan meningkatkan daya beli masyarakat di daerah. Peningkatan daya beli masyarakat ini tentu akan menjadikan tambahan pendapatan bagi daerah, sehingga kemandirian keuangan daerah meningkat. Selain itu, jumlah penduduk yang menempati suatu daerah juga akan berpengaruh terhadap pelayanan yang diberikan oleh pemerintah daerah. Semakin besar populasi penduduk berarti tingkat permintaan dan penawaran akan meningkat dan menguntungkan banyak pihak dengan kata lain semakin besar jumlah penduduk juga akan meningkatkan perekonomian suatu daerah.

\section{Pengaruh Jumlah SKPD Terhadap Terhadap Kemandirian Keuangan Daerah}

Hasil pengujian hipotesis kelima memiliki nilai t sebesar -1.956 dan nilai koefisien regresi sebesar -0.410 dengan nilai sig. 0.055. Hal ini berarti jumlah SKPD tidak mempengaruhi kemandrian keuangan daerah karena nilai sig. $>\alpha(0.05)$, yaitu $0.055>0.05$. Berdasarkan hasil uji t dapat disimpulkan bahwa jumlah skpd tidak berpengaruh terhadap kemandirian keuangan daerah. Pengelolaan keuangan daerah tidak terlepas dari peran SKPD sesuai dengan fungsi dan tugasnya. Namun peran SKPD dalam melakukan pengelolaan terhadap kekayaan daerah belum berjalan sesuai dengan mestinya, ini bisa dilihat dari masih terdapatnya beberapa permasalahan dalam pengelolaan aset seperti panyalahgunaan kas dan persediaan.

Peran SKPD dalam meningkatkan kemandirian daerah belum dilaksanakan secara optimal sehingga tidak dapat meningkatkan kinerja pemerintah. Sehingga SKPD dianggap kurang mampu dalam melaksanakan tugas dan wewenangnya dalam upaya memandirikan daerah. Seharusnya SKPD dalam mengelola pelaksanaan pemerintah daerah harus memiliki upaya dalam meningkatkan efisiensi, efektifitas dan menciptakan nilai tambah dalam mengelola aset, dan menjadikan ini modal awal bagi pemerintah daerah untuk melakukan pengembangan kemampuan keuangannya serta dapat menunjang peran dan fungsi pemerintah daerah sebagai pemberi pelayanan publik kepada masyarakat.

\section{Pengaruh Belanja Pegawai Terhadap Terhadap Kemandirian Keuangan Daerah}

Hasil pengujian hipotesis keenam memiliki nilai t sebesar 0.112 dan nilai koefisien regresi sebesar 0.008 dengan nilai sig. 0.911. Hal ini berarti belanja pegawai tidak berpengaruh terhadap kemandirian keuangan daerah karena nilai sig. $>\alpha(0.05)$, yaitu $0.911>$ 0.05 Berdasarkan hasil uji $\mathrm{t}$ dapat disimpulkan bahwa belanja pegawai tidak mempengaruhi kemandirian keuangan daerah.

Belanja pegawai berperan sebagai alat kompensasi yang diberikan kepada perangkat daerah sebagai imbalan atas pekerjaan yang telah dilaksanakan, dan juga sebagai pendorong untuk meningkatkan produktifitas kerja para perangkat daerah dalam melaksanakan pembangunan daerah. Hasil penelitian ini sejalan dengan penelitian yang dilakukan oleh Darwis, E. T. R. (2015) dan Simatupang, F. F. (2016) yang menyatakan bahwa belanja pegawai tidak berpengaruh terhadap kemandirian keuangan daerah. Hal ini mengindikasikan bahwa semakin tinggi belanja pegawai akan menyebabkan kemandirian pembangunan daerah akan semakin rendah.

Diasumsikan bahwa semakin besar komposisi belanja pegawai semakin besar belanja operasi dan pemeliharaan sarana publik. Yang berarti kinerja Pemerintah Daerah akan semakin baik. Belanja pegawai disatu sisi memberikan pengaruh postif terhadap kemandirian daerah, dimana besarnya belanja pegawai bisa mendorong produktifitas kinerja para perangkat daerah tersebut. Namun di sisi lain, belanja pegawai juga dapat memberikan pengaruh yang negatif terhadap kemandirian daerah, hal ini dikarenakan besarnya belanja 
pegawai akan mempengaruhi besarnya tingkat pengeluaran daerah yang kemudian dapat membebani stabilitas keuangan daerah.

\section{Pengaruh Leverage Terhadap Terhadap Kemandirian Keuangan Daerah}

Hasil pengujian hipotesis ketujuh memiliki nilai t sebesar 2.057 dan nilai koefisien regresi sebesar 1.826 dengan nilai sig. 0.044. Hal ini berarti leverage berpengaruh terhadap kemandirian keuangan daerah karena nilai sig. $<\alpha(0.05)$, yaitu $0.044<0.05$ Berdasarkan hasil uji t dapat disimpulkan bahwa leverage mempengaruh kemandirian keuangan daerah.

Pada sektor publik khusunya entitas pemerintah daerah, rasio leverage ini digunakan untuk mengukur perbandingan antara utang dengan ekuitas (kekayaan bersih pemerintah daerah). Hasil penelitian menunjukan bahwa semakin tinggi leverage maka pemerintah daerah semakin mandiri. Hal tersebut bisa terjadi karena pemerintah daerah bagus dalam mengelola utang untuk keperluan pelayanan publik, sehingga masyarakat semakin sejahtera.

Pada sektor publik khusunya entitas pemerintah daerah, rasio leverage ini digunakan untuk mengukur perbandingan antara utang dengan ekuitas (kekayaan bersih pemerintah daerah). Hasil penelitian menunjukan bahwa semakin tinggi leverage maka pemerintah daerah semakin mandiri. Hal tersebut bisa terjadi karena pemerintah daerah bagus dalam mengelola utang untuk keperluan pelayanan publik, sehingga masyarakat semakin sejahtera.

\section{SIMPULAN, KETERBATASAN DAN \\ Simpulan}

Berdasarkan penelitian dan pembahasan yang telah dijelaskan sebelumnya maka kesimpulan penelitian ini adalah sebagai berikut:

1. Ukuran pemerintah daerah berpengaruh negatif terhadap kemandirian keuangan daerah.

2. Umur prmerintah daerah berpengaruh negatif terhadap kemandirian keuangan daerah.

3. Status pemerintah daerah berpengaruh positif terhadap kemandirian keuangan daerah.

4. Jumlah penduduk berpengaruh positif terhadap kemandirian keuangan daerah.

5. Jumlah SKPD berpengaruh negatif terhadap kemandirian keuangan daerah.

6. Belanja pegawai berpengaruh negatif terhadap kemandirian keuangan daerah.

7. Leverage berpengaruh positif terhadap kemandirian keuangan daerah.

\section{Keterbatasan}

Keterbatasan dalam penelitian ini adalah:

1. Nilai adjusted $R 2$ adalah $11.3 \%$ yang berarti kontribusi variabel independen terhadap variabel dependen hanya $11.3 \%$. Sehingga masih banyak variabel lain yang dapat mempengaruhi kemandirian keuangan daerah.

2. Penelitian ini hanya dilakukan di kabupaten/kota Provinsi Sumatera Barat dari periode waktu 2015-2019, dan ini menyebabkan hasil penelitian akan berbeda jika dilakukan di daerah lain mengingat perbedaan karakteristik masing-masing wilayah di Indonesia.

\section{Saran}

1. Bagi pemerintah daerah diharapkan lebih memperhatikan faktor yang bisa meningkatkan kemandirian keuangan pemerintah daerah, supaya kemandirian keuangan pemerintah daerah bisa lebih ditingkatkan.

2. Bagi peneliti selanjutnya diharapkan dapat menambah variabel-variabel dalam penelitian ini untuk menguji pengaruh kemandirian keuangan daerah. Untuk penelitian selanjutnya agar dapat menambahkan sumber data yang digunakan maupun jangka waktu penelitian agar mendapatkan hasil yang lebih maksimal dan akurat. 


\section{DAFTAR PUSTAKA}

Abdullah, S. (2004, October). Perilaku oportunistik legislatif dalam penganggaran daerah: Pendekatan Principal-Agent Theory. In Makalah disajikan pada Seminar Antarbangsa di Universitas Bengkulu, Bengkulu (pp. 4-5).

Abdullah, S., \& Asmara, J. A. (2006). Perilaku oportunistik legislatif dalam penganggaran daerah. Simposium Nasional Akuntansi, 9, 23-26.

Anwar, D. K. (2019). Determinan Tingkat Kemandirian Keuangan Daerah di Provinsi Jawa Timur Tahun 2010-2017.

Chairany, M. (2010). Analisis Total Penduduk Kecamatan Padang Bolak Pada Tahun 2012"(Tugas Akhir). Medan: Universitas Sumatera Utara.

Darwis, E. T. R. (2015). Pengaruh Belanja Modal Dan Belanja Pegawai Terhadap Tingkat Kemandirian Keuangan Daerah Pada Kabupaten/Kota Provinsi Sumatera Barat (Studi Empiris Pada Kabupaten dan Kota Provinsi Sumatera Barat). Jurnal Akuntansi, 3(1).

Firmansyah, I. (2017). Analisis Faktor Yang Mempengaruhi Kemandirian Keuangan Daerah Di Provinsi Lampung Tahun Anggaran 2011-2015.

Ghozali, I. (2011). Aplikasi Analisis Multivariate Dengan Program IBM dan SPSS. Semarang: BP Universitas Diponegoro.

Gomes, R. C., Alfinito, S., \& Albuquerque, P. H. M. (2013). Analyzing local government financial performance: evidence from Brazilian municipalities 2005-2008. Revista de Administração Contemporânea, 17(6), 704-719.

Groves, S. M., W.M. Godsey, dan M.A. Shulman. (2001). Financial Indicator for Local Government. Public Finance International City Management Association 9: 243-255.

Hadi, D. A., \& Setiawan, M. A. (2020). Pengaruh Ukuran Pemerintah Daerah, Kekayaan Pemerintah Daerah, Dan Jumlah Penduduk Terhadap Pengungkapan Internet Budgeting Reporting. JURNAL EKSPLORASI AKUNTANSI, 2(1), 2099-2114.

Hadi, W. (2010). Pengaruh likuiditas dan leverage terhadap kemandirian daerah (studi terhadap laporan keuangan pemerintah daerah tahun anggaran 2007 di wilayah Provinsi Aceh). Jurnal Telaah dan Riset Akuntansi, 3(1), 29-51.

Halim, A. (2007). Manajemen Keuangan Bisnis. Bogor: Penerbit Ghalia Indonesia.

Halim, A. (2013). Akuntansi Keuangan Daerah (ed. 3) Koran. Penerbit Salemba.

Halim, A., \& Abdullah, S. (2010). Hubungan dan Masalah Keagenan di Pemerintah Daerah. Jurnal Akuntansi Pemerintah, 2(1), 53-64.

Imawan, R., \& Wahyudin, A. (2014). Analisis kemandirian keuangan daerah Provinsi Jawa Tengah tahun anggaran 2010-2012. Accounting Analysis Journal, 3(2).

Kuncahyono, H. (2015). Pengaruh karakteristik pemerintah daerah terhadap kemandirian keuangan pada pemerintah daerah di Jawa Timur (Doctoral dissertation, UNS (Sebelas Maret University)).

Martono, N. (2015). Metode Penelitian Sosial. Jakarta: PT Raja Grafindo Persada.

Minarsih, R. A. (2015). Pengaruh size, wealth, leverage dan intergovernmental revenue terhadap kinerja keuangan pemerintah daerah di jawa tengah (Doctoral dissertation, UNIVERSITAS NEGERI SEMARANG).

Mukarramah, H. (2017). Pengaruh Pajak Daerah Dan Retribusi Daerah Terhadap Kemandirian Keuangan Daerah Di Lima Kabupaten/Kota Provinsi Jawa Barat Tahun 2008-2014 (Bachelor's thesis, Jakarta: Fakultas Ekonomi dan Bisnis UIN Syarif Hidayatullah Jakarta).

Nahartyo, E., \& Utami, I. (2019). Panduan Praktis Riset Eksperimen. Jakarta Barat: Penerbit Indeks Jakarta.

Patrick, P. A. (2007). The determinants of organizational innovativeness: The adoption of GASB 34 in Pennsylvania local government (Doctoral dissertation, Pennsylvania State University). 
Pratiwi, N. (2016). Pengaruh Karakteristik Pemerintah Derah terhadap Kemandirian Keuangan serta Dampaknya terhadap Pertumbuhan Ekonomi dan Indeks Pembangunan Manusia di Indonesia (Doctoral dissertation, STIE YKPN).

Purnama, W. A. (2016). Pengaruh Komponen PAD, Leverage, dan Dana Perimbangan Terhadap Kemandirian Keuangan Pemerintah Daerah (Studi pada Kabupaten/Kota. di Provinsi Lampung).

Putri, E. R. (2014). Pengaruh Karakteristik Pemerintah Daerah Terhadap Kinerja Keuangan Pemerintah Daerah (Studi pada Pemerintah Provinsi di Indonesia Tahun 20082012) (Doctoral dissertation, Universitas Lampung).

Santoso, A. (2017). Pengaruh Karakteristik Pemerintah Daerah Terhadap Kinerja Keuangan Daerah (Studi Empiris Pada Kabupaten/Kota di Jawa Dan Bali Tahun 2015) (Doctoral dissertation, Universitas Jenderal Soedirman).

Setyaningrum, D., \& Syafitri, F. (2012). Analisis pengaruh karakteristik pemerintah daerah terhadap tingkat pengungkapan laporan keuangan. Jurnal Akuntansi dan Keuangan Indonesia, 9(2), 154-170.

Simatupang, F. F. (2016). Pengaruh Dana Perimbangan, Belanja Modal, Dan Belanja Pegawai Terhadap Tingkat Kemandirian Keuangan Daerah Pada Pemerintah Kabupaten/Kota Di Provinsi Sumatera Utara.

Sugiyono. (2017). Metode Penelitian Kuantitatif, Kualitatif dan R\&D. Bandung: CV Alfabeta. Tangkilisan, H. (2007). Manajemen Publik. Jakarta: Grasindo.

Taryoko, (2016) "Analisis Faktor-faktor yang Mempengaruhi Kemandirian Keuangan Daerah di Daerah Istimewa Yogyakarta Periode 2006-2013”. Skripsi. Fakultas Ekonomi Universitas Negeri Yogyakarta.

Undang-Undang Nomor 23 Tahun 2014 tentang Pemerintahan Daerah.

Undang-Undang Nomor 33 tahun 2004 tentang Perimbangan Keuangan Antara Pemerintah Pusat dan Daerah.

Utami, B. (2018). Pengaruh Kinerja Pendapatan Asli Daerah, Belanja Modal, Dan Belanja Pegawai Terhadap Tingkat Kemandirian Keuangan Daerah (Studi Empiris pada Pemerintah Daerah Kabupaten/Kota di Provinsi Daerah Istimewa Yogyakarta) (Doctoral dissertation, Skripsi, Universitas Muhammadiyah Magelang).

Wahyuni, E., \& Ardini, L. (2018). Pengaruh Kinerja Pendapatan Asli Daerah Belanja Modal dan Belanja Pegawai Terhadap Tingkat Kemandirian Keuangan Daerah. Jurnal Ilmu Dan Riset Akuntansi (JIRA), 7(6).

Waliyyani, G. M., \& Makhmud, A. (2015). Pengaruh karakteristik pemerintah terhadap tingkat pengungkapan laporan keuangan pemerintah daerah di Indonesia. Accounting Analysis Journal, 4(2). 